CZASOPISMO INŻYNIERII LĄDOWEJ, ŚRODOWISKA I ARCHITEKTURY JOURNAL OF CIVIL ENGINEERING, ENVIRONMENT AND ARCHITECTURE JCEEA, t. XXXIV, z. 64 (3/II/17), lipiec-wrzesień 2017, s. 245-255, DOI:10.7862/rb.2017.169

\author{
Maciej PIEKARSKI ${ }^{1}$
}

\title{
IDEA WIRTUALNEJ REKONSTRUKCJI IN SITU UTRACONYCH FRAGMENTÓW HISTORYCZNEJ PRZESTRZENI URBANISTYCZNEJ RZESZOW
}

\begin{abstract}
W referacie została przedstawiona koncepcja wirtualnej rekonstrukcji oraz prezentacji w technologii rzeczywistości rozszerzonej fragmentów nieistniejącej zabudowy historycznego centrum Rzeszowa, bezpośrednio w miejscach pierwotnej lokalizacji. Celem proponowanego przedsięwzięcia jest upowszechnienie wśród mieszkańców i osób odwiedzających miasto, wiedzy o dawnym układzie urbanistycznym tam, gdzie uległ on na przestrzeni ostatnich kilkudziesięciu lat istotnym przeobrażeniom. Realizacja projektu przyczyni się do wzmocnienia tożsamości wytypowanych miejsc, poprzez wzbogacenie ich krajobrazu kulturowego o warstwy przynależne do poprzednich epok, bez fizycznej ingerencji w warstwę aktualną. W referacie określono miejsca potencjalnie najbardziej odpowiednie do zrealizowania projektu, dokonując wyboru tych, które znajdują się wzdłuż uczęszczanych ciągów pieszych, przestrzeń po istniejących wcześniej budynkach pozostaje niezabudowana, zakres przeobrażeń urbanistycznych jest znaczący oraz istnieje zachowana dokumentacja rysunkowa i fotograficzna stanu pierwotnego. Dopuszcza się, że wizualizacja nieistniejącej zabudowy może zostać zrealizowana za pomocą urządzeń optycznych lub elektronicznych. Zdaniem autora, w każdym przypadku, największą korzyść przyniosą urządzenia stacjonarne. Umiejscowienie ich w przestrzeni miejskiej zapewni równy do nich dostęp, będzie prowokować do korzystania, zaś w przypadku wykonania w postaci atrakcyjnych wzorniczo obiektów małej architektury, wzbogaci krajobraz miasta. Wybór Rzeszowa, jako miejsca realizacji projektu, jest szczególnie trafny ze względu na skalę przemian urbanistycznych, skutkujących zniknięciem wielu kameralnych miejsc, których małomiasteczkowy koloryt był daleko odległy od krajobrazu współczesnego.
\end{abstract}

Słowa kluczowe: Rzeszów, układ urbanistyczny, rzeczywistość rozszerzona, rekonstrukcja wirtualna

\footnotetext{
${ }^{1}$ Maciej Piekarski, Politechnika Rzeszowska, Zakład Projektowania Architektonicznego i Grafiki Inżynierskiej, al. Powstańców Warszawy 12, 35-959 Rzeszów; tel.: 17865 1839; e-mail: mgpiekar@prz.edu.pl
} 


\section{Wprowadzenie}

Rzeszów jest miastem, które na przestrzeni ostatnich kilkudziesięciu lat doświadczyło nieporównywalnej z innymi polskimi miastami zmiany skali, w wymiarze terytorialnym piętnastokrotnej oraz około siedmiokrotnej w wymiarze ludnościowym. Przeobrażenia przestrzenne spowodowały zanik małomiasteczkowego kolorytu, zaś zagnieżdżenie krajobrazu współczesnego Rzeszowa w dziedzictwie historycznym, stało się dla osoby nie znającej przeszłości miasta, trudne do zidentyfikowania.

Przeszłość ma dla tożsamości każdego miasta ogromne znaczenie. Ze względu na efemeryczność czasu, ślady przeszłości mogą być zapisane wyłącznie w przestrzeni. Dla odczucia jej niezmienności nie wystarczy świadomość stałości koordynat. Konieczna jest obecność trwałych form, zamieniających fragmenty przestrzeni w miejsca, którym towarzyszy genius loci. W przestrzeni przeorganizowanej trudniej znaleźć zaginiony czas. Wyzwaniem, które w takiej sytuacji może być podjęte, jest wirtualna rekonstrukcja utraconego krajobrazu, przy obecnej technologii, mająca szanse realizacji również bezpośrednio in situ.

\section{Zmiany struktury przestrzennej Rzeszowa}

\subsection{Rozrost terytorialny $\mathrm{i}$ ludnościowy miasta}

Rzeszów do lat 30-tych XX wieku był niewielkim miastem, stanowiącym zaplecze gospodarcze i administracyjne dla obszaru obejmującego najbliższe okolice. Miasto pozbawione było zakładów przemysłowych, a zasadniczym czynnikiem podtrzymującym jego ekonomiczną stabilność, był liczny garnizon wojskowy. Powolny rozrost miasta obejmował tereny położone w bezpośrednim sąsiedztwie obszarów już zurbanizowanych.

Momentem zwrotnym w historii miasta stała się decyzja rządu z 1936 roku o budowie Centralnego Okręgu Przemysłowego, której skutkiem była lokalizacja w Rzeszowie wytwórni silników PZL oraz fabryki sprzętu artyleryjskiego H. Cegielskiego. Lokalizacja wytwórni silników oraz osiedli mieszkaniowych dla pracowników obu fabryk została wyznaczona w odległości ok. 1,5 km od krańców dotychczasowej zabudowy miejskiej, która w ówczesnej skali miasta stanowiła znaczący dystans.

Kolejnym impulsem dla rozwoju miasta była decyzja z 1944 roku o ustanowieniu w Rzeszowie stolicy województwa. Ten fakt, polityka rozwoju przemysłu maszynowego oraz migracja ludności wiejskiej do miast, wygenerowały dalsze zmiany urbanistyczne, zapoczątkowane w 1951 roku i trwające nieprzerwanie do 1989 roku. W ich rezultacie powstały nowe osiedla mieszkaniowe rozszerzające zwarty obszar zabudowy miejskiej, wzniesione na terenach uprzednio rolniczych. Towarzyszącym skutkiem była destrukcja układów ruralistycznych kilku podmiejskich wsi, zwłaszcza Drabinianki i Staroniwy. 
Po 1989 roku struktura miasta uległa kolejnym przemianom. Dokonano największego w historii powiększenia jego obszaru, przebudowano i rozbudowano układ komunikacyjny oraz wzniesiono obiekty o niespotykanej wcześniej kubaturze lub wysokości. Tereny położone na obrzeżach, w tym w obrębie przyłączonych wsi, m.in. Słociny, Białej, Budziwoja, Przybyszówki, zostały wyłączone z eksploatacji rolniczej i objęte zabudową mieszkaniową, na skutek czego uległy zatarciu formy krajobrazu typowe dla osadnictwa wiejskiego.

\subsection{Przeobrażenia w obrębie historycznego centrum Rzeszowa}

Rozrostowi Rzeszowa towarzyszyły zmiany urbanistyczne w historycznym centrum miasta. Pierwsze ich nasilenie nastąpiło w okresie okupacji niemieckiej i obejmowało wyburzenia budynków w celu poprawy komunikacji lub zagrożonych zawaleniem się, a także unicestwienie zabudowy na terenie zajętym na getto dla Żydów, po jego likwidacji [1].

Istotne zmiany z tego okresu to:

- wyburzenie tzw. domu Klarneta przy ul. Grunwaldzkiej, w celu uproszczenia przejazdu od ul. Zielonej (ob. Sobieskiego) w kierunku ul. Sokoła,

- likwidacja zabudowy w centralnej części placu Śreniawitów, a tym samym przekształcenie placu w jednoprzestrzenne wnętrze architektoniczne,

- likwidacja zespołów kamienic po północnej i południowej stronie ratusza,

- likwidacja zabudowy pośrodku ulicy Mickiewicza, wyodrębniającej wnętrza nieistniejących dziś placów Dwóch Studni i Mickiewicza,

- wyburzenie zespołu kamienic w obrębie obecnego skweru Cichociemnych,

- częściowe wyburzenie zabudowy w obrębie tzw. Różanki.

Drugi etap szerokich zmian to okres po 1951 roku, a zwłaszcza dekada lat

60-tych [2]. Ze względu na wzrost natężenia ruchu samochodowego, zrealizowane zostały podjęte w okresie międzywojennym decyzje o przebudowie układu komunikacyjnego w centrum miasta. W tym celu dokonano przebicia ulicy Piłsudskiego od placu Wolności w kierunku zachodnim oraz ciągu ulic Cieplińskiego i Lisa Kuli, wiążąc je skrzyżowaniem w formie ronda. Realizując te działania wyburzono fragmenty zabudowy ul. Grunwaldzkiej, Asnyka i placu Wolności, a także ulic Sokoła i Zamkowej. W ramach porządkowania przestrzeni i przygotowania terenu pod nie do końca do dziś zrealizowane inwestycje, dokonano wyburzeń również $\mathrm{w}$ innych miejscach, np. w rejonie placu Wolności oraz na Różance. Oprócz zredukowania zabudowy, w ścisłym centrum miasta wzniesiono także kilka nowych obiektów. Forma niektórych z nich stanowi dysonans w przestrzeni architektonicznej, przez co kamuflują one równie skutecznie historyczną proweniencję miejsc, na które oddziałują. 


\section{Pojęcie rzeczywistości rozszerzonej i jej charakterystyka}

Rzeczywistość rozszerzona jest pojęciem określającym powiązanie świata rzeczywistego z komponentami generowanymi komputerowo, umożliwiające percepcję obiektów wirtualnych bezpośrednio w doświadczanej przez obserwatora przestrzeni trójwymiarowej. Zostało użyte po raz pierwszy w 1992 roku dla określenia technologii polegającej na wyświetlaniu obrazu na transparentnym ekranie, nie zasłaniającym widoku naturalnego otoczenia [3]. Oprócz takiej technologii, równoprawne jest użycie monitora, na którym obraz obiektów wirtualnych jest nałożony na obraz rejestrowany na bieżąco przez kamerę. Pomimo odniesień do technologii komputerowej, istotą rzeczywistości rozszerzonej jest współobecność obiektów realnych oraz niematerialnych reprezentacji takich obiektów, stwarzająca iluzję postrzegania jako fizyczne obiektów nieistniejących. Można zatem uznać, że rzeczywistością rozszerzoną jest też np. synteza malarstwa iluzjonistycznego i wnętrz architektonicznych, jak i dopuścić do jej kreowania, oprócz urządzeń elektronicznych, urządzenia optyczne.

Na zróżnicowanie systemów rzeczywistości rozszerzonej, oprócz rodzaju zastosowanej technologii, wpływ ma kilka innych kryteriów:

- stopień wciągnięcia użytkownika w percepcję środowiska wirtualnego, różny przy stosowaniu urządzeń tablicowych lub nagłownych,

- sposób syntezowania wirtualności i rzeczywistości (obserwacja środowiska rzeczywistego za pośrednictwem kamery lub okiem nieuzbrojonym),

- właściwości generowanego obrazu (mono- lub stereoskopowy),

- sposób lokalizacji urządzeń odbiorczych (stacjonarne lub mobilne).

Najprostszym zabiegiem kreującym rzeczywistość rozszerzoną jest posłużenie się przezroczystą płytą z narysowanym lub wygrawerowanym obrazem obiektów wirtualnych, które mogą być obserwowane nieuzbrojonym okiem na tle obrazu obiektów realnie istniejących (rys. 1.). Efektem ewentualnego wykonania takiego rysunku w technice anaglifowej, byłaby trójwymiarowość obrazu, osiągana pod warunkiem stosowania specjalnych okularów. Efekt stereoskopowy może zostać osiągnięty również w wyniku obserwacji za pomocą binokularu pary obrazów różnych dla każdego oka, łączących się w mózgu w jeden obraz przestrzenny. Jeżeli poszczególne płaskie obrazy zostaną umieszczone na materiale transparentnym, obraz wirtualny ulegnie nałożeniu na obraz rzeczywisty.

Z urządzeń elektronicznych, najszersze jak dotądzastosowanie znajdują urządzenia oparte na obecności monitora, wyświetlającego zsyntetyzowany obraz środowiska rzeczywistego i wirtualnego, a więc tablety, smartfony itp. (rys. 2.). Ponieważ ich mankamentem jest nikły stopień wciągnięcia użytkownika w percepcję środowiska wirtualnego, większą popularność zdobywają urządzenia nagłowne.Najprostsze $\mathrm{z}$ nich mają formę obudowy dla smartfona, na którego podzielonym ekranie wyświetlane są odrębne obrazy dla prawego i lewego oka. Bardziej zawansowanym produktem są gogle OculusRift wymagające współpracy z komputerem, co stanowi ich istotną wadę. Najnowszym osiągnię- 
ciem są okulary Hololens. Okulary, są wyposażone we własny komputer oraz przyrządy określające położenie w przestrzeni, obraz rzeczywistości wirtualnej jest wyświetlany na materiale transparentnym, zaś środowisko rzeczywiste jest postrzegane przez użytkownika wyłącznie za pomocą jego narządu wzroku.

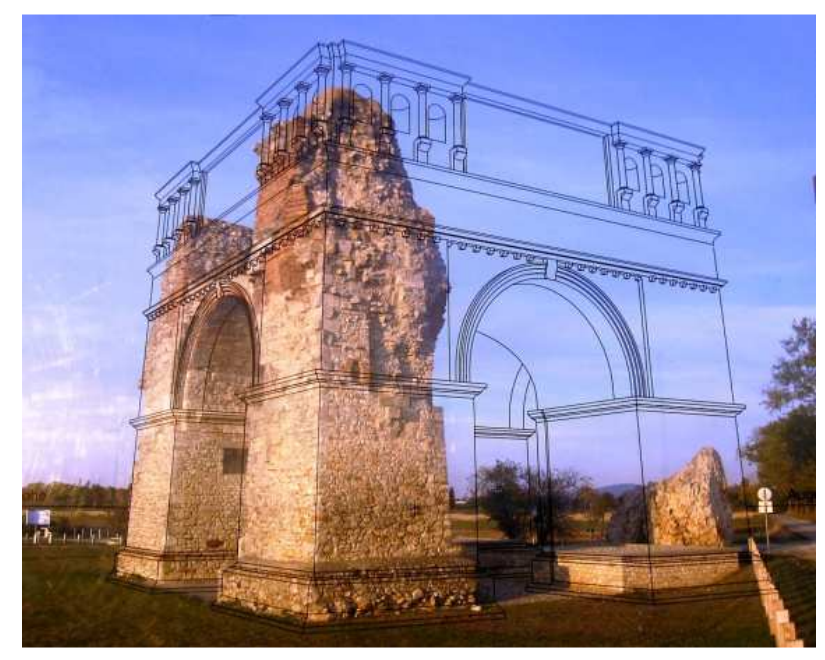

Rys. 1. Wizualizacja bramy do rzymskiego obozu Carnuntum, na podstawie: commons.wikimedia.org

Fig. 1. Visualization of gateway to the Roman camp Carnuntum, based on commons.wikimedia.org

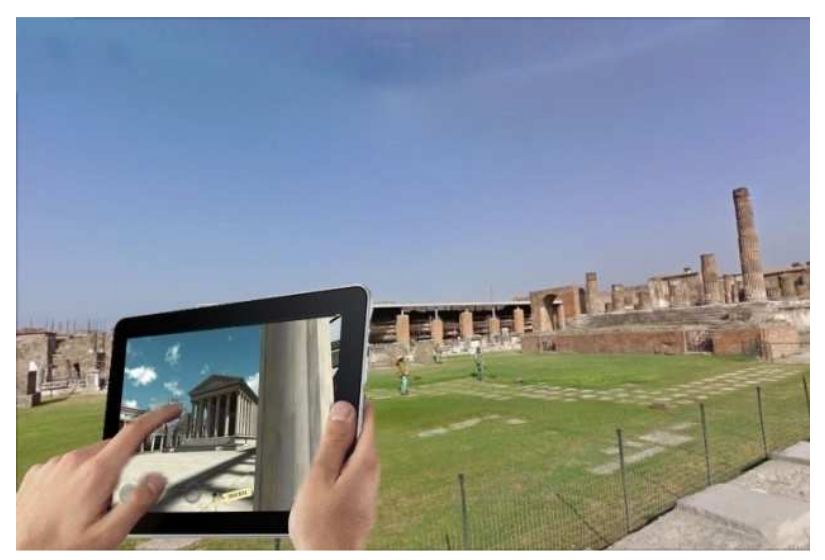

Rys. 2. Wizualizacja nieistniejących obiektów w Pompejach, na podstawie: www.netminds.it

Fig. 2. Visualization of non-existing objects in Pompeii, based on: www.netminds.it 


\section{Wybór miejsc właściwych dla wizualizacji zmian przestrzeni urbanistycznej w systemie rzeczywistości rozszerzonej}

\subsection{Uwagi ogólne}

System rzeczywistości rozszerzonej jest już stosowany dla rekonstrukcji warstw historycznych zabudowy, lecz odbywa się to za pośrednictwem ogólnodostępnych platform cyfrowych, z których zainteresowani mogą pobierać obrazy, korzystając z własnych urządzeń mobilnych. Intencją autora, jest zastosowanie w Rzeszowie urządzeń stacjonarnych, które poprzez obecność w przestrzeni publicznej, prowokowałyby do korzystania z nich. Poprzez atrakcyjną formę, urządzenia mogą wzbogacić przestrzeń architektoniczną, a oryginalną funkcją wpłynąć korzystnie na postrzeganie Rzeszowa jako miasta innowacyjnego. Ze względu na stabilizację w terenie, rozważane może być zastosowanie do kreacji rzeczywistości rozszerzonej, zarówno urządzeń optycznych, jak i elektronicznych. Przewagą technologii elektronicznej jest możliwość redukowania części obrazu środowiska wirtualnego, niewidocznej np. na skutek poruszania się na pierwszym planie samochodów. W każdym przypadku, stacjonarność ułatwia kompilację obrazu środowiska wirtualnego i rzeczywistego.

Problemami niezależnymi od kwestii technicznych są zagadnienia możliwości rekonstrukcji wirtualnej obiektów z punktu widzenia obecnego stanu przestrzeni, w której się znajdowały, a także ze względu na dostępność materiału dokumentującego ich wygląd. Jeżeli chodzi o pierwszy problem, rekonstrukcja in situ jest względnie łatwa w miejscach, w których przestrzeń pozostaje niezabudowana i niezadrzewiona. Drugi problem dotyka zagadnienia wiarygodności, która w działalności konserwatorskiej, a rekonstrukcję wirtualną można uznać za konserwację przez dokumentację, stanowi pryncypium. Rekonstrukcja, mająca za cel przypomnienie utraconego krajobrazu urbanistycznego nie wymaga odtworzenia obiektów architektonicznych ze wszystkimi detalami. Istotne jest, aby zgodnie z prawdą były odwzorowane ich gabaryty. W celu odróżnienia od substancji zachowanej, co jest zasadą konserwatorską, wskazane jest obrazowanie obiektów rekonstruowanych w sposób uproszczony, np. za pomocą wizerunku linearnego. Można więc abstrahować np. od kolorystyki elewacji, trudnej do odgadnięcia z czarno-białych fotografii. Wizualizacja obiektów za pośrednictwem urządzeń stacjonarnych przynosi korzyść, ponieważ nie wymaga odtworzenia pełnej struktury przestrzennej rekonstruowanych obiektów, a jedynie wybranych wyglądów, widocznych z przestrzeni publicznej. Regułą jest większa dostępność fotografii przedstawiających elewacje frontowe budynków, niż dokumentujących wyglądy podwórek i oficyn.

Oprócz materiału fotograficznego, który w przypadku Rzeszowa jest wyjątkowo bogaty, m.in. za sprawą odkrycia w 1997 roku zbioru kilku tysięcy negatywów pochodzących z dawnej pracowni fotograficznej Edwarda Janusza, źródłem wiedzy dla rekonstrukcji nieistniejących obiektów architektonicznych mo- 
gą być mapy katastralne oraz projekty techniczne budynków. Wartość materiału fotograficznego jest o tyle cenna, że przedstawia on z całą pewnością stan faktycznie istniejący, a przede wszystkim inspiruje wyobraźnię rekonstruktora.

\subsection{Wytyczne szczegółowe}

Intencją autora jest wirtualna rekonstrukcja historycznej zabudowy Rzeszowa szczególnie w tych miejscach, w których kształtowała ona kameralne

a)

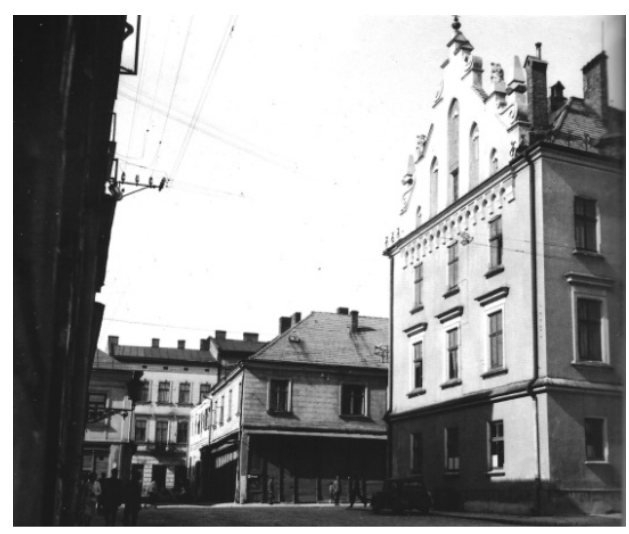

b)

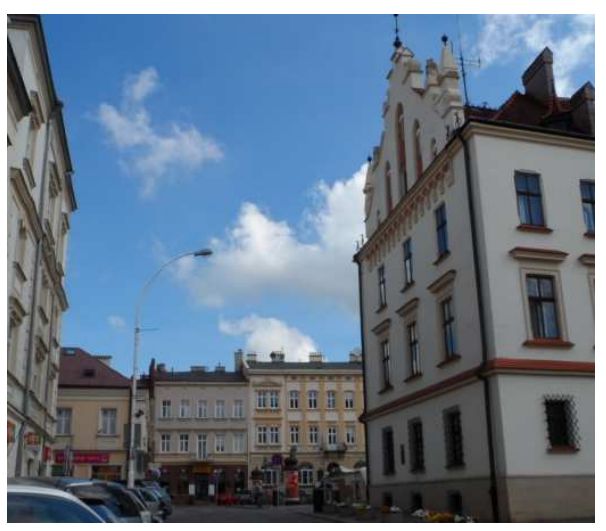

Rys. 3. Ul. Słowackiego obok ratusza: a) przed rokiem 1943, na podstawie [4], b) obecnie (fotografia autora)

Fig. 3. Słowacki street next to the town hall: a) before 1943, based on [4], b) presently (autho'sr photo)

a)

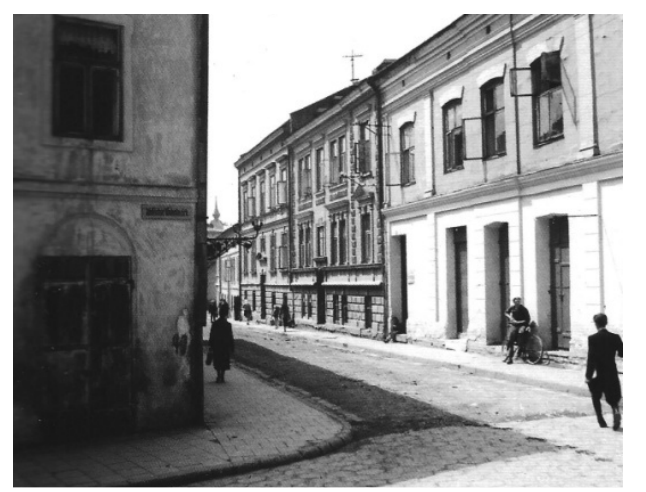

b)

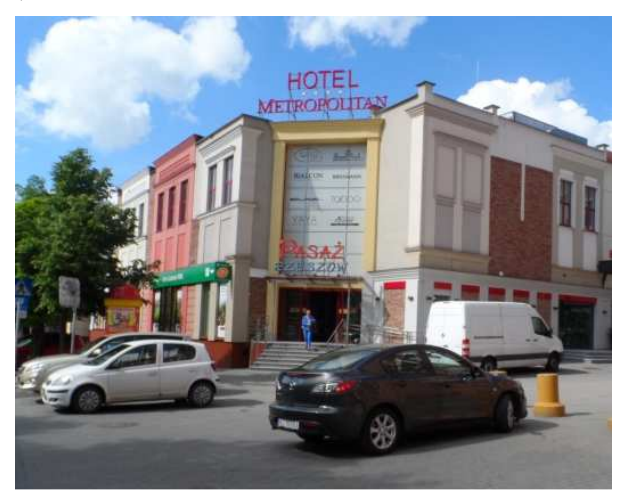

Rys. 4. Skrzyżowanie ulic Słowackiego i Króla Kazimierza: a) przed rokiem 1943, na podstawie [4], b) obecnie (fotografia autora)

Fig. 4. Crossing of Słowacki and King Kazimierz streets: a) before 1943, based on [4], b) presently (author's photo) 
wnętrza urbanistyczne, nadające miastu specyficznego kolorytu, współcześnie zatracone na rzecz otwartych przestrzeni. Jednym z takich miejsc jest teren po północnej stronie ratusza, stanowiący aktualnie lokalizację wejścia do Podziemnej Trasy Turystycznej oraz estrady dla imprez plenerowych, zabudowany do 1943 roku kamienicami, które wyodrębniały fragment ul. Słowackiego, nazywany ulicą Kurzą (rys. 3.). Urządzenia kreujące obraz tych budynków mogą być zlokalizowane na płycie Rynku oraz przy ul. Słowackiego, po zachodniej stronie ratusza. Ta lokalizacja jest dogodna również dla obserwacji miejsca po jego południowej stronie, zajętego dzisiaj przez parking, a do roku 1941 zabudowanego kamienicami, a także południowo-wschodniego narożnika skrzyżowania ulic Króla Kazimierza i Słowackiego, zabudowanego do 1943 roku (rys. 7a). Lokalizacja kolejnego stanowiska obserwacyjnego, po przeciwnej stronie ul. Słowackiego, pozwoliłaby na wgląd w historyczny obraz istniejącej do końca lat 60-tych XX wieku zabudowy prawej strony tej ulicy, której pierwotny kierunek był odchylony w kierunku zachodnim od obecnego (rys. 4.).

a)

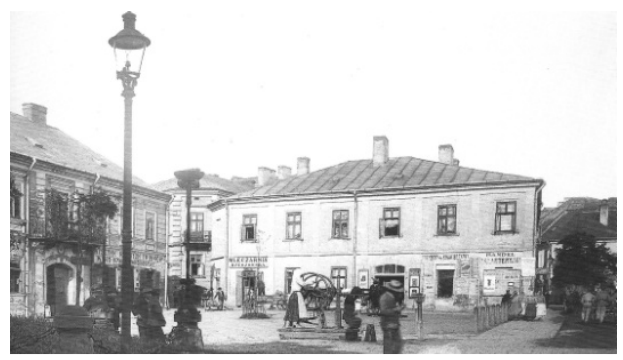

b)

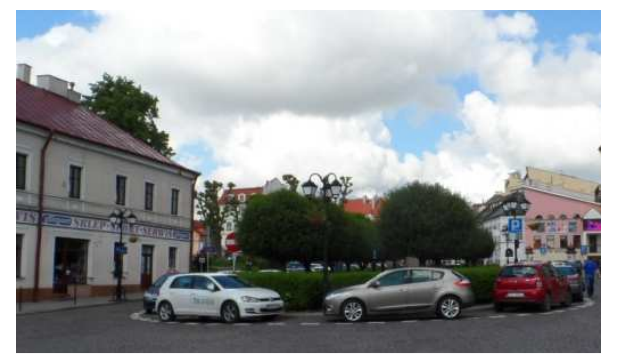

Rys. 5. Ulica Mickiewicza: a) do lat 40. XX w. na podstawie [5], b) obecnie (fotografia autora)

Fig. 5. Mickiewicz street: a) until the 40s of the XX century [5], b) presently (author's photo)

a)

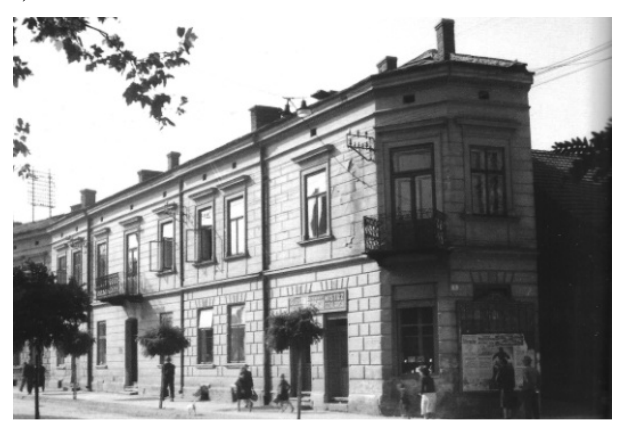

b)

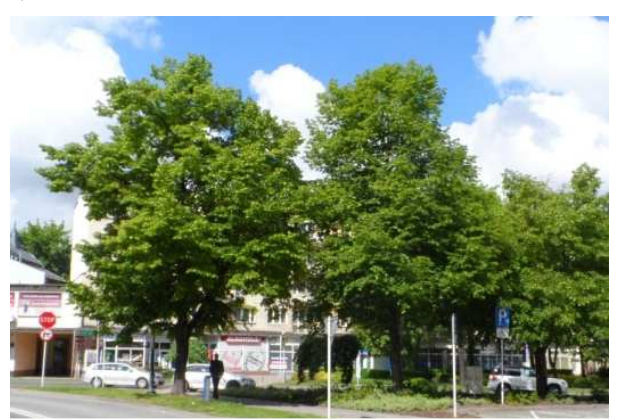

Rys. 6. Ulica Zamkowa: a) do lat 60. XX w. na podstawie [4], b) obecnie (fotografia autora)

Fig. 6. Zamkowa street: a) until the 60s of the twentieth century [4], b) presently (author's photo) 
Opisany wyżej rejon miasta jest jednym z najbardziej przeobrażonych na obszarze historycznego centrum. Czynnikami, które utrudniłyby percepcję dawnego krajobrazu w obecnej przestrzeni, są zadrzewienie i budynek handlowohotelowy, zajmujący przestrzeń dawnej ulicy. Projekcja rzeczywistości rozszerzonej w tym miejscu wymaga zastosowania zaawansowanej technologii informatycznej. Problem parkujących samochodów może zostać wyeliminowany przez wyłączenie ruchu samochodowego na tym odcinku ul. Słowackiego.
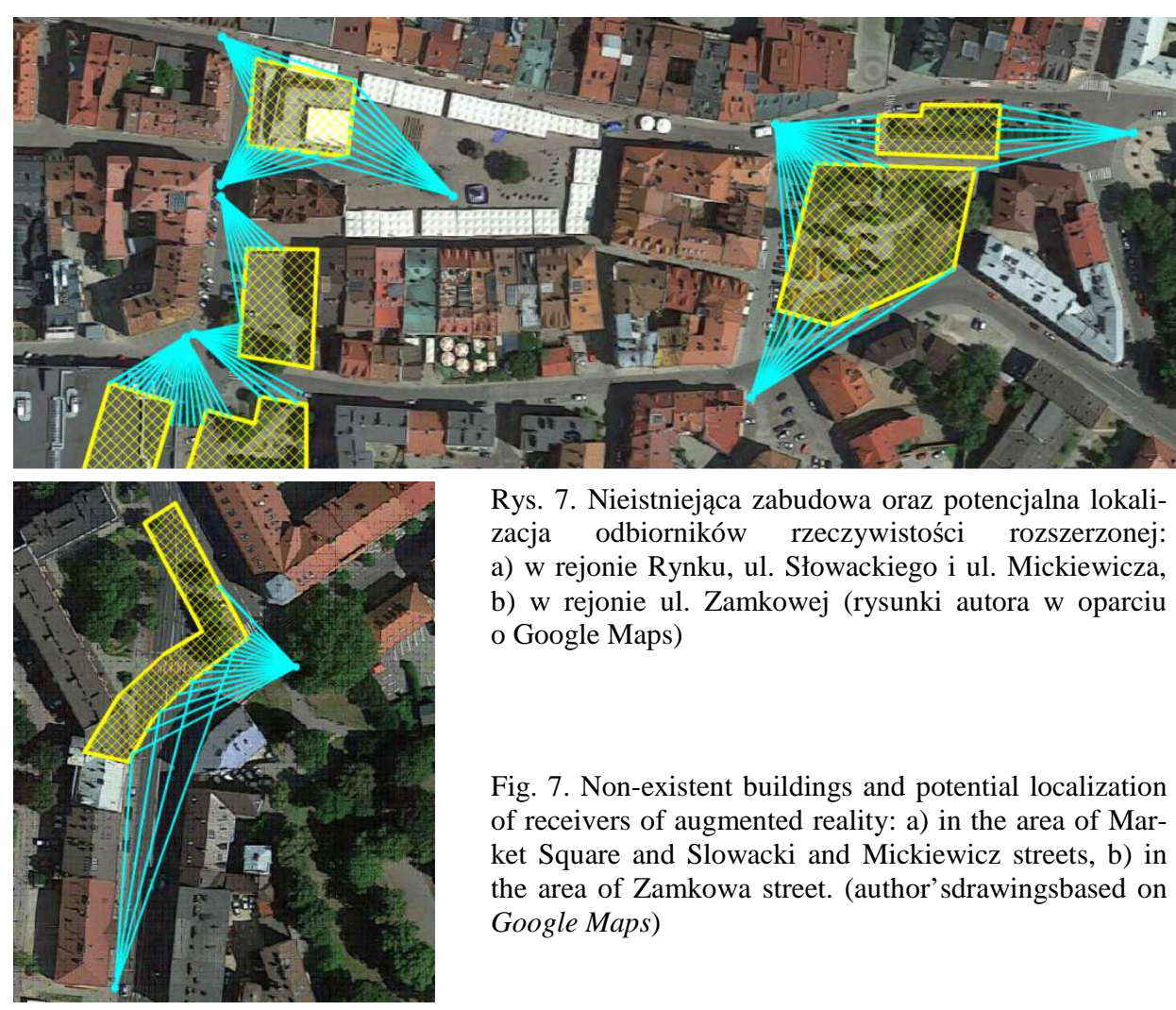

Rys. 7. Nieistniejąca zabudowa oraz potencjalna lokalizacja odbiorników rzeczywistości rozszerzonej: a) w rejonie Rynku, ul. Słowackiego i ul. Mickiewicza, b) w rejonie ul. Zamkowej (rysunki autora w oparciu o Google Maps)

Fig. 7. Non-existent buildings and potential localization of receivers of augmented reality: a) in the area of Market Square and Slowacki and Mickiewicz streets, b) in the area of Zamkowa street. (author'sdrawingsbased on Google Maps)

Kolejnym obszarem predestynowanym do rekonstrukcji jest zabudowa południowej pierzei ulicy Mickiewicza oraz Placu Cichociemnych. Budynki stojące niegdyś pośrodku współczesnej ulicy Mickiewicza wyodrębniały przestrzenie dwóch placów: Mickiewicza, w rejonie skrzyżowania z ulicami Gałęzowskiego i Kreczmara (rys. 5) oraz Dwóch Pomp, w rejonie skrzyżowania z ul. Joselewicza. Możliwa jest lokalizacja urządzeń kreujących obrazy tych placów, jednego w odcinku ul. Mickiewicza przylegającym do Rynku i drugiego w pobliżu pomnika Mickiewicza. Urządzenie rekonstruujące zabudowę Placu Cichociemnych mogłoby zostać zlokalizowane na Placu Garncarskim (rys. 7a). 
Jednym z miejsc oddalonych od Rynku, godnych przypomnienia dawnego układu urbanistycznego, jest rejon obecnego skweru ks. Walentego Bala, na obszarze którego istniała kiedyś zabudowa północnej pierzei ulicy Zamkowej (rys. 6) oraz zachodniej pierzei ulicy Skarbowej z charakterystyczną sylwetką willi „Aniela”. Jeden z projektorów rzeczywistości rozszerzonej mógłby znaleźć swoją lokalizację przy ul. Zamkowej, w sąsiedztwie XVIII-wiecznego platana, inny w rejonie skrzyżowania ul. Kraszewskiego i Lisa-Kuli. To samo miejsce byłoby również dogodne dla prezentacji zabudowy placu Śreniawitów, istniejącej przed rokiem 1940 (rys. 7b).

\section{Podsumowanie}

Wymienione miejsca znajdują się w bliskości Rynku, licznie odwiedzanego przez mieszkańców i turystów. Udostępnienie rzeczywistości rozszerzonej w takiej lokalizacji nie powinno pozostać niezauważone. Autor uważa, że rozmieszczenie podobnych urządzeń $w$ innych rejonach historycznego centrum miasta spowoduje rozszerzenie obszaru aktywności społecznej, generując tam zapotrzebowanie na inne usługi podwyższające jakość przestrzeni publicznej.

\section{Literatura}

[1] Kotula F.: Z dziejów Rzeszowa 1939-1944. Losy rzeszowskich zabytków i pamiątek, MITEL, Rzeszów 1998.

[2] Encyklopedia Rzeszowa (red. J. Draus), RS DRUK, Rzeszów 2004.

[3] Caudell T., Mizell D.: Augmented Reality: An Application of Heads-up Display Technology to Manual Manufacturing Processes. Proceedings of the Twenty-Fifth Hawaii International Conference on System Sciences,1992, str. 659-669.

[4] Propaganda i rzeczywistość. Album wystawy „Wczorajsze dzisiaj. Rzeszów z lat okupacji 1939-1945. Ze zbiorów Bogusława Kotuli”, IPN, Rzeszów, 2008.

[5] Rzeszów: pejzaż dawnego miasta: Rzeszów 1905-1918 w obiektywie Andrzeja Bujniaka. Studio Kolor, Rzeszów 2002.

\section{IDEA OF VIRTUAL RECONSTRUCTION IN SITU OF LOST FRAGMENTS OF THE HISTORIC URBANISTIC SPACE OF RZESZÓW}

\section{S u m m a r y}

The paper presents the concept of virtual reconstruction and presentation in the augmented reality of the fragment of non-existing buildings in the historical center of Rzeszów, directly in the place of the original location. The purpose of the proposed project is to disseminate the knowledge of the old urban layout, where it has been significantly changed over the last few decades.The implementation of the project will help to strengthen the identity of the selected sites, by enriching their cultural landscape with layers belonging to previous eras, without physical destruction of the current layer.The paper identifies the places the most suitable for the project, selecting the ones 
that are located along the pedestrian paths, the remains undeveloped, the extent of urban transformations is significant, and the original drawing and photographic documentation is preserved.It is possible that the visualization of non-existing buildings can be realized by means of optical or electronic devices. According to the author, in any case, the most beneficial will be the stationary equipment. Placing them in urban space will provoke to use them, and in the case of the realization in the form of visually attractive objects of small architecture, will enrich the city landscape. The choice of Rzeszów as a project location is particularly relevant due to the scale of urbanistic changes, which resulted in the disappearance of many cameral places, characterisd by small-town landscape, very different from the present one.

Keywords: Rzeszów, urbanistic layout, augmented reality, virtual reconstruction.

Przestano do redakcji: 09.06.2017 r.

Przyjęto do druku: 01.09.2017 r. 
